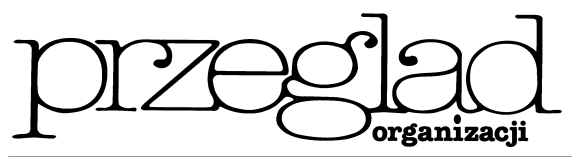

\title{
Ocena kreatywności firmy
}

https://doi.org/10.33141/po.2005.03.09

\section{Ewa Jerzyk, Grzegorz Leszczyński}

\section{Uwagi wstępne}

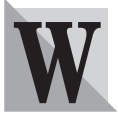

zrost zainteresowania problemem kreatywności doprowadził do rozwoju badań nad ludzką twórczością oraz związanymi z nią procesami myślowymi. Wyniki takich badań umożliwiają porównywanie i ocenianie kreatywności osób oraz - co wydaje się ważniejsze dla firm - analizowanie, jak przebiegają procesy twórcze w zależności od warunków pracy. Zapotrzebowanie przedsiębiorstw na wyniki takich badań jest duże, istnieje bowiem uzasadniona nadzieja, że dostarczą one informacji, jak zarządzać organizacją, by sprzyjać twórczym zachowaniom pracowników.

Jednocześnie toczy się dyskusja nad zasadnością i sposobami badania kreatywności. Samo zdefiniowanie pojęcia kreatywności stanowi trudność z uwagi na jego wieloznaczność. Wieloznaczność ta utrudnia badanie kreatywności, komplikując zbieranie danych i ich interpretację. Występuje szeroka gama poglądów - od negowania sensu oceniania kreatywności, po oferowanie zestawów narzędzi, które temu służą. Nie analizując tych różnorodnych podejść, przedstawimy zagadnienia związane $\mathrm{z}$ badaniem i ocenianiem kreatywności.

\section{Przedmiot badania kreatywności}

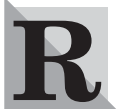
ozważając zagadnienie badania kreatywności w biznesie, zasadnicze jest pytanie, co lub kto będzie mu podlegać? Czy będzie to pracownik firmy, jego pomysły lub dzieła, sam proces dochodzenia do nich, czy też może cała firma? Badając kreatywność pracowników, trzeba pamiętać, że jest ona zdolnością potencjalną, co oznacza, że nie musi przejawiać się w wypracowanych pomysłach. Można nazwać kreatywnym kogoś, kto nie przedstawił żadnych nowatorskich rozwiąań. Osoba twórcza nie jest tożsama z twórca, a tym bardziej z innowatorem, który wprowadza pomysły w życie (choć w biznesie wielką wartość ma dysponowanie każdą z tych cech). Samo posiadanie umiejętności twórczego myślenia nie przesądza o tym, że wszyscy w takim samym stopniu potrafimy z niej korzystać, podobnie jak przy innych umiejętnościach. Uzasadnia to sens badań, które pozwalają mierzyć i oceniać kreatywność poszczególnych osób. Ich celem jest dowiedzenie się, czy dana osoba może być „źródłem” kreatywnych rozwiązań, czyli czy posiada potencjał twórczy. Ocena taka z reguły doko-
Przegląd Organizacji, Nr 3 (782), 2005, ss. 36-39 www.przegladorganizacji.pl Towarzystwo Naukowe Organizacji i Kierownictwa (TNOiK) nywana jest w przedsiębiorstwach podczas przyjmowania nowych pracowników lub okresowej oceny personelu firmy.

Przyjmując założenie J.P. Guilforda o egalitarnym charakterze kreatywności, nie ma sensu badanie, którego celem jest sprawdzenie, czy dany pracownik jest kreatywny - jest bowiem taki z założenia. Interesujące jest za to dążenie do ustalenia, w jakich dziedzinach dana osoba ma największy potencjał kreatywny, tak by odpowiednio wykorzystać go w firmie. Można również starać się zmierzyć i porównywać kreatywność osób. Ocenianie kreatywności osób wiąże się najpierw z jej pomiarem, a dopiero później określeniem w uproszczeniu - czy wynik jest dobry czy nie. Trzeba zdawać sobie sprawę, że pomiar i ocena kreatywności pracowników budzą wątpliwości metodologiczne i etyczne.

Nieco inaczej wygląda sytuacja, w której oceniane są materialne lub niematerialne dzieła pracowników. Ocena taka jest wpisana w zarządzanie przedsiębiorstwem, które wymaga podejmowania decyzji na zasadzie wybierania najlepszego spośród różnych rozwiązań. Jednakże nie zawsze wybór danego pomysłu będzie oznaczać, że został on oceniony jako najbardziej twórczy, jako że kryteria podejmowania decyzji mogą być bardzo złożone.

Podczas badania kreatywności materialnych i niematerialnych efektów pracy ludzkiej mniejsze znaczenie ma ich autor - liczą się cechy opracowanego rozwiązania czy koncepcji. Z taką oceną mamy do czynienia w różnych dziedzinach biznesu. Na przykład odnosząc się do telewizyjnego spotu reklamowego, twierdzimy raczej, że jest nowatorski; nie mówimy zaś, że jest wynikiem pracy twórczych osób. Zakłada się przy tym, że dzieła niestandardowe są efektem pracy osób o wysokim potencjale twórczym. Sytuacja komplikuje się jednak, gdy oceniane jest dzieło powstałe dzięki pracy zespołu pracowników. Nawet jeżeli rezultat ich pracy uznamy za bardzo nowatorski, nie będzie to upoważniało do wysokiego mniemania o kreatywności każdego członka grupy. Być może indywidualnie nie mają oni wysokich zdolności twórczych, ale dzięki pracy zespołowej stworzyli coś przełomowego.

W niektórych dziedzinach życia gospodarczego spotykamy instytucjonalną ocenę kreatywności dzieł. Przykładem sa konkursy akcji reklamowych. Warto jednak zwrócić uwagę, że choć laury dostaje autor lub firma, w której jest zatrudniony, to z reguły oceniane są dzieła, a nie ludzie. Co więcej, nowatorski charak- 
ter jest tylko jednym z elementów oceny - najważniejszym miernikiem jest zwykle efektywność kampanii promocyjnej ${ }^{1}$. Domniemywa się jedynie, że kreatywność dzieła przyczyniła się do efektywności, choć wiemy, że to dość duże uproszczenie.

Badaniu może także podlegać sam proces dochodzenia do pomysłów. Określenie, w jaki sposób i w jakich warunkach przebiega powstawanie twórczych rozwiązań, jest obszarem badań psychologii twórczości. W naukach o zarządzaniu widać zaś coraz większe zapotrzebowanie na kompleksowe opisanie tych procesów, co być może pozwoliłoby na wzrost efektywności zarządzania kreatywnością. Ustalenie, jakie warunki sprzyjaja procesowi kreacji nowatorskich pomysłów w przedsiębiorstwie oraz umiejętność ich stwarzania wydają się posiadać priorytetowe znaczenie w praktycznym wykorzystaniu kreatywności. Obecny stan wiedzy na temat uwarunkowań kreatywności jest znaczny, problemem zaś jawi się przeniesienie tej wiedzy na grunt zarządzania przedsiębiorstwem.

Rozważając, czy badaniu i ocenie powinna podlegać osoba, jej sposób myślenia czy też wynikające z niego pomysły, zauważamy, że w praktyce menedżerowie oceniają kreatywność pracowników na podstawie ich pomysłów, a niekiedy nawet przez pryzmat umiejętności ich wdrożenia. Świadczą o tym wyniki badań, przedstawione w dalszej części artykułu.

Często potocznie mówi się, że jakaś firma jest bardziej kreatywna niż inne. Rzetelne porównanie przedsiębiorstw pod tym względem wymaga skomplikowanych badań i analiz. Dlatego coraz częściej spotykamy się z próbami ustalania kreatywności całej firmy. Podejście takie odnosi się do co najmniej trzech wymiarów:

- badania kadry,

- badania „klimatu” sprzyjającego kreatywności,

- badania zachowania firmy na rynku.

Pierwsze zagadnienie wiąże się z określaniem kreatywności osób lub efektów ich pracy. Pamiętajmy, że utożsamianie kreatywności firmy ze średnią kreatywności jej pracowników jest daleko idącym uproszczeniem. Dlatego dąży się raczej do poznania twórczych zachowań personelu. Badania „klimatu” organizacji skupiają się na zidentyfikowaniu warunków, jakie panują w przedsiębiorstwie do twórczej pracy zatrudnionych w nim osób. Innym podejściem jest wnioskowanie o kreatywności firm na podstawie analizowania ich rynkowych zachowań. Przejawem takiego myślenia jest pogląd, według którego kreatywne są firmy posiadające wiele patentów.

\section{Kontekst badania i oceny kreatywności}

W definiowaniu kreatywności przejawia się odniesienie do nowości, nowatorskiego charakteru pomysłu. Badając kreatywność, musimy doprecyzować pojęcie nowości - w stosunku do czego pomysł powinien być nowy i kto go będzie pod tym kątem klasyfikować? Czy kreatywna będzie strategia, której nikt w danej branży nie zastosował, ale jest dobrze znana w innej? Zależy to od podejścia: tak - bo strategia jest nowatorska dla danej firmy i jej konkurentów, nie - bo została skopiowana z innego sektora. Można również stwierdzić, że przystosowanie takiej strategii do warunków funkcjonowania firmy wymagało twórczego podejścia.

Nie można uznawać za dzieło tylko tego, co jest absolutnie nowe. Ustalenie takiego absolutu byłoby $\mathrm{w}$ praktyce niezmiernie trudne i powodowałoby negację twórczego charakteru kontynuacji, inspiracji, modyfikacji i usprawnień. Twórcza modyfikacja dobrze znanego produktu może przecież doprowadzić do przełomowej zmiany na rynku (przeprojektowanie standardowego roweru na rower zjazdowy przez Gary'ego Fishera i stworzenie nowej kategorii rowerów MTB). Ustalenie takie powoduje jednak znaczną trudność w badaniu kreatywności. Jak na przykład porównywać kreatywność nowego pomysłu, będącego modyfikacją wcześniejszych koncepcji, z pomysłem, który powstał na bazie kontynuacji znanych już idei?

Definiowanie kreatywności odnosi się także do wartości wytworu pracy twórczej. Powoduje to podobne trudności, jak przy określaniu „nowości” dzieła w stosunku do czego i przez kogo będzie określana wartość. Inne wartości mają znaczenie w sztuce (piękno), w nauce (prawda), a całkiem odmienne w życiu gospodarczym (użyteczność, wartość dla klienta, możliwość realizacji). Zwróćmy uwagę, że ocenianie kreatywności przez pryzmat nowości i wartości może zmieniać się wraz z upływem czasu (np. niekiedy strategie firm wchodzacych na polski rynek wydają się nowatorskie, dopóki nie dowiadujemy się, że były one wcześniej stosowane w kilkunastu innych krajach).

Znaczenie kontekstu przy określaniu kreatywności widać na przykładzie projektowania i wprowadzania na rynek nowych produktów. Nie wszystko, co jest nowe dla konsumenta, jest odkrywcze dla producenta (np. testowanie przez firmę Renault w bolidach Formuły 1 nowatorskich rozwiązań, które po pewnym czasie są stosowane w seryjnych samochodach osobowych). Produkty nowe dla mieszkańców pewnych krajów nie są niczym nowatorskim w innych (np. Nestle wprowadza na nowe rynki popularną w Grecji kawę frappe).

Jak widać, przede wszystkim od podejścia do nowości dzieła, a także jego wartości zależy, co ostatecznie nazwiemy kreatywnym. Warto pamiętać, że z punktu widzenia kontekstu badania kreatywności ważne znaczenie ma także cały zestaw warunków, $\mathrm{w}$ jakich będzie ono przeprowadzane.

\section{Kryteria oceny kreatywności}

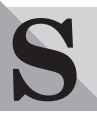

amo zdefiniowanie istoty kreatywności nie przesądza jeszcze, że ustalony jest zbiór kryteriów, z jakich można korzystać podczas jej badania. Różnorodność spojrzeń na twórczość rodzi trudności z określeniem, jakie wymogi powinna spełniać osoba lub jej dzieło, by uznać je za kreatywne. Dobranie kryteriów decyduje o tym, które osoby lub dzieła uznamy za kreatywne, a które nie ${ }^{2}$. 
Kryteria, które stosuje się do oceny twórczości artystycznej lub naukowej, mają mniejszą użyteczność w biznesie, jednak warto się z nimi zapoznać. Są to zazwyczaj obiektywnie stwierdzane dowody społecznego uznania dzieła lub jego autora. W przypadku malarstwa może to być aukcyjna cena obrazu, w muzyce liczba słuchaczy na koncertach lub sprzedany nakład płyt. W pracy naukowej stosowany jest indeks cytowań, nakład i liczba wydań książki danej osoby. Kryteria te opierają się na założeniu, że im większa wartość dzieła, tym większe jego uznanie (popularność) w społeczeństwie ${ }^{3)}$.

Dużą popularność zyskał system kryteriów zaproponowany przez J.P. Guilforda. Osoba badana podaje rozwiązania problemu, które ocenia się ze względu na płynność, giętkość oraz oryginalność według następujących założeń.

- Płynność określa łatwość w znajdowaniu pomysłów - im jest ich więcej, tym większa płynność myślenia.

- Giętkość oznacza skłonność do zmieniania sposobu myślenia - im pomysły są bardziej różnorodne, wszechstronne, tym myślenie jest bardziej giętkie. Giętkość spontaniczna to samoczynna zmiana kierunku myślenia, a giętkość adaptacyjna określa reakcję myślenia, wymuszoną warunkami lub poleceniami.

- Oryginalność odnosi się do zdolności tworzenia nietypowych rozwiązań. Wyznacza ją częstość występowania danego pomysłu - im jest on rzadszy w całej populacji, tym bardziej oryginalny.

Na pozór ocena przez pryzmat płynności wydaje się trywialna i nieadekwatna jako ocena kreatywności, bo duża liczba zaproponowanych pomysłów może nie mieć żadnej wartości i być nieprzydatna. W procesie kreacji wśród zgłaszanych propozycji znajdują się także zazwyczaj rozwiązania banalne, czasami nie związane z problemem lub całkowicie nierealne, które w kolejnych etapach należy odrzucić, ale mimo to wpływają na ocenę płynności.

Im więcej pomysłów jesteśmy w stanie przedstawić, tym większe prawdopodobieństwo, że wśród nich znajdą się te najlepsze. Nie wiadomo, jaka liczba propozycji byłaby satysfakcjonujacca i zawierała te najbardziej zadowalające. Niektórzy starają się przedstawić pewne wskazówki do określenia optymalnej liczby pomysłów, twierdząc, że podczas wymyślania propozycji pierwsze trzy są najczęściej przeciętne, trzy następne wykraczają już poza przeciętność, a ostatnie trzy są zwykle najbardziej kreatywne i najlepsze, a więc innowacyjne i godne wykorzystania ${ }^{4)}$. Jednak w dalszym ciągu liczba pomysłów, spełniająca kryterium płynności, nie jest znana.

Kryteria opracowane przez J.P. Guilforda pozwalają oceniać osoby (a nie ich wytwory) zawsze w odniesieniu do pewnej badanej grupy. Ich zaletąjest stosunkowo mała komplikacja w dokonywaniu pomiaru oraz czytelny, mierzalny wynik. Niestety, ocena przeprowadzona na tej podstawie nie mówi nic o wartości wytworzonych pomysłów. Z drugiej strony zwolennicy tej metody odrzucają takie zarzuty twierdząc, że liczba pomysłów rodzi ich jakość. Później rozszerzono trzy omówione kryteria o staranność, która w przy- padku biznesu odnosi się do czynności wykonanych dla przedstawienia pomysłu. Kreatywność to zatem również umiejętność zakomunikowania w odpowiedniej formie i treści dzieła, pomysłu czy rozwiązania, które zostanie ostatecznie przyjęte lub odrzucone przez osobę, grupę czy społeczeństwo.

Omówione kryteria oceny kreatywności - giętkość, płynność, oryginalność i staranność wydają się możliwe do zastosowania w biznesie, o ile zostaną wzbogacone o dodatkowe elementy podlegające ocenie. Z pewnością takim kryterium powinna być realność pomysłu czy zgłoszonego rozwiązania. Na obecnym etapie naszych badań nad kreatywnościa w przedsiębiorstwach trudno jednoznacznie sprecyzować ten element oceny kreatywności. Realność pomysłu można bowiem traktować jako jego wykonalność, możliwość zastosowania czy przyszłą efektywność związaną $\mathrm{z}$ wdrożeniem. Z drugiej strony włączenie tego kryterium do oceny kreatywności łączy się z zagrożeniem dla samego procesu kreatywnego, który z natury posługuje się myśleniem lateralnym, metaforycznym i wykorzystaniem wyobraźni. A zatem, czy wiedząc, że pomysł jest oceniany w kategoriach wykonalności i efektywności nie jesteśmy zniechęcani do posługiwania się myśleniem kreatywnym?

Zebrane wyniki badań wskazują, że włączenie realności do zbioru ocen kreatywności jest konieczne, aby zarządzanie kreatywnością znalazło większe zastosowanie w biznesie. Rodzą się następne pytania. Czy kryteria zaproponowane przez Guilforda na potrzeby biznesu należy wzbogacić o dodatkowe suwerenne kryterium - realności, czy raczej każde z kryteriów analizować w kontekście realności (płynność w relacji do realności, giętkość w odniesieniu do realności i oryginalność a realność). Niektórzy badacze kreatywności stosują kompromisowe rozwiązania. Mianowicie, oprócz wykorzystania tradycyjnych miar kreatywności w postaci płynności, oryginalności i różnorodności, stosują inne kryteria, bardziej adekwatne i precyzyjne do problemu, który jest rozwiązywany. $\mathrm{Na}$ przykład w ocenie kreatywności strategicznych planów marketingowych wyższych uczelni ekonomicznych MBA zastosowano następujące oceny:

- obecność w planie (lub brak) wizji przyszłości oraz różnorodność propozycji działań urzeczywistniających tę wizję;

- obecność (lub brak) zaskakujących pomysłów, które nie byłyby ekstrapolacją wcześniejszych rozwiązań stosowanych na rynku;

- liczba zgłoszonych oryginalnych pomysłów działań, które nie były stosowane wcześniej;

- pomysły przełamujące konwencję rynku, burzące dotychczasowe sposoby działania;

- praktyczność rozwiązań ${ }^{5)}$.

Odmienne podejście do oceniania kreatywności bazuje na założeniu, że nie trzeba szukać zestawu odpowiednich kryteriów, bo jeśli jakieś dzieło jest twórcze, to właściwie dobrani obserwatorzy są w stanie to zauważyć. Wystarczy więc znaleźć osoby o dużej wiedzy w danej dziedzinie, a te będą w stanie ocenić pomysł lub dzieło. I w tym przypadku pojawia się pro- 
blem wyboru osób - sędziów, którzy będą dokonywać oceny, jakie zastosować kryteria doboru sędziów i jak określić zestaw cech podlegających ocenie.

Jeśli dążymy do oceniania kreatywności przedsiębiorstwa, natrafiamy na problem związany z niedostatkiem opracowanych kryteriów i systemów ocen. Przeprowadzone badania wśród menedżerów i kadry zarządzającej polskich firm potwierdziły niedostatek wiedzy i umiejętności w zakresie dokonywania oceny kreatywności. Te braki przekładają się na nieskuteczność narzędzi motywacyjnych stosowanych w celu stymulacji kreatywności pracowników.

\section{Ocena kreatywności pracowników w świetle przeprowadzonych badań}

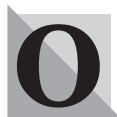

cena ludzkiej kreatywności stwarza wiele problemów zarówno w warstwie teoretycznej, jak i w praktyce. Przeprowadzone przez nas badania w pełni potwierdziły to spostrzeżenie ${ }^{6)}$. Na podstawie zebranych wyników badań można przypuszczać, że badani menedżerowie dokonują ocen kreatywności względem swoich pracowników. A zatem kreatywność stanowi przedmiot oceny pracownika zatrudnionego w małym lub średnim przedsiębiorstwie. Nie wiadomo jednak, czy deklaracje badanych menedżerów nie były związane z tematem seminarium, w którym uczestniczyli. Interesujacym rezultatem przeprowadzonego badania było uzyskanie informacji na temat kryteriów, według których oceniana jest kreatywność pracowników.

Przynajmniej jedno kryterium oceny kreatywności pracowników podało blisko dwie trzecie ankietowanych menedżerów. Wśród uzyskanych wyników wyróżniono kryteria niewymierne i kryteria wymierne. Najczęściej wskazywane kryteria niewymierne to: - ciekawość pomysłów, • przydatność, • innowacyjność, zaangażowanie.

Ponadto zwracano uwagę na: entuzjazm, wiedzę, doświadczenie, talent, rzetelność.

Z kolei ocen o charakterze mierzalnym najwięcej respondentów dokonywało posługując się efektami pracy i efektami sprzedaży. Poza tym podano także następujące kryteria: pozyskiwanie nowych klientów, poziom obsługi klientów, pozytywna ocena klientów, pozycja firmy na rynku, liczba wariantów rozwiązań.

Przedstawione wyniki pozwalają przypuszczać, że większość ankietowanych respondentów nie stosuje jasno określonych kryteriów oceny kreatywności. Można też zastanawiać się, czy zidentyfikowane kryteria rzeczywiście pozwalają na określenie poziomu kreatywności pracowników. Ciekawym wnioskiem z przeprowadzonych badań było także potwierdzenie słuszności dołączenia do zbioru kryteriów ocen kreatywności cech wymiernych. Wydaje się, że zastosowanie kryteriów mierzalnych do oceny kreatywności zachęci do wykorzystywania kreatywności w biznesie i uskuteczni politykę motywacyjną.

\section{Podsumowanie}

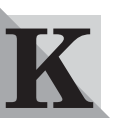
reatywność jest wartościową umiejętnością we współczesnej, konkurencyjnej gospodarce. Efekty myślenia twórczego są coraz częściej doceniane w przedsiębiorstwach, zauważa się ich niezbędność i traktuje jako znaczącą szansę na rozwój. Literatura, a zwłaszcza z zakresu psychologii twórczości, dostarcza wielu kryteriów ocen kreatywności, które nie zawsze mogą być zastosowane w praktyce gospodarczej. Aby jednak kreatywność znalazła większe wykorzystanie w biznesie, należy przyjąć pewne kryteria ocen, które umożliwią zarządzanie kreatywnością, jak również wprowadzanie narzędzi motywujących pracowników do myślenia kreatywnego. $\mathrm{Z}$ pewnością sprzyjać temu będzie jasne określenie tego, co ma być oceniane. Z ekonomicznego punktu widzenia przydatne okazuje się ocenianie poziomu kreatywności pracowników oraz kreatywności efektu (nowatorskiego pomysłu bądź rozwiązania). Kryteriami oceny kreatywności mogą być płynność, giętkość, oryginalność połączone z realnością oraz staranność, choć nie wyklucza się przyjęcia innych. Powyższe kryteria powinny być zawsze stosowane z uwzględnieniem uwarunkowań, które mogą wykluczać sensowność ich stosowania.

W ocenie kreatywności nie można posługiwać się kryteriami ocen innowacyjności. Kreatywność poprzedza innowacyjność, którą określa się jako praktyczną aplikację pomysłów i rozwiązań będących wynikiem procesu kreacji. Przyjęcie miary innowacyjności jako oceny kreatywności byłoby znacznym ograniczeniem. dr Ewa Jerzyk dr Grzegorz Leszczyński Katedra Strategii Marketingowych Akademia Ekonomiczna w Poznaniu

\section{PRZYPISY}

1) Na przykład w Międzynarodowym Konkursie Marketingu Bezpośredniego „Boomerang” kampanie promocyjne ocenia się pod względem: efektywności (30-50\% wartości ogólnej oceny kampanii), strategii (10-30\%), kreacji (15$30 \%)$, integracji kanałów komunikacji (10-30\%) i innowacyjności (5-25\%).

2) Opisując kryteria ocen posiłkowano się książką: E. NĘCKI, Psychologia twórczości, Gdańskie Wydawnictwo Psychologiczne, Gdańsk 2001, s. 24-34 i 190-199.

3) W Polsce stosowana jest ocena punktowa każdego artykułu i książki, uzależniona od rangi czasopisma lub wydawnictwa.

4) J. WHEELER, Moc innowacyjnego myślenia, Wydawnictwo Amber, Warszawa 2001, s. 83.

5) Wyniki eksperymentu badającego kreatywność planów strategicznych uczelni MBA prezentuje H. RIQUELME, How to Develop More Creative Strategic Plans: Results from an Empirical Study, „Creativity and Innovation Management", nr 1/2000, s. 14-20.

6) Badania zostały przeprowadzone w maju 2004 r. na próbie 83 respondentów. $Z$ szerszym opisem metodologii przeprowadzonego badania, jak też jego wyników, można zapoznać się w internecie na stronie www.swiatmarketingu.pl 